\title{
Luteolytic effect of oestrone sulphate on cyclic beef heifers
}

\author{
R. M. Eley, W. W. Thatcher and F. W. Bazer* \\ Dairy and *Animal Science Departments, University of Florida, Gainesville 32611, U.S.A.
}

\begin{abstract}
Summary. The action of oestrone sulphate on luteal function was tested in cyclic beef heifers. Once daily injection of 28 or $56 \mathrm{mg}$ oestrone sulphate in corn oil beginning on Day 10 of the cycle had a significant luteolytic effect as compared to corn oil-treated controls.
\end{abstract}

\section{Introduction}

Oestradiol is luteolytic in the cow (Brunner, Donaldson \& Hansel, 1969; Wiltbank, Ingalls \& Rowden, 1961) but luteotrophic in the pig (Gardner, First \& Casida, 1963; Frank, Bazer, Thatcher \& Wilcox, 1977) when administered during the luteal phase of the cycle. Reports of free oestrogen production by Day-12 pig blastocysts, conjugation of free oestrogens by the pig endometrium and the existence of a sulphatase in the ovary (Perry, Heap, Burton \& Gadsby, 1976) implied a luteotrophic nature of the conjugated form. Conjugated oestrogens are present in the fetal fluids and maternal plasma of the early pregnant cow (Robertson \& King, 1975; Eley, Thatcher \& Bazer, 1979) and bovine trophoblast is capable of converting androstenedione to free oestrogens in vitro (R. M. Eley, unpublished observation). An experiment was therefore designed to test the possible luteotrophic nature of conjugated oestrone in normally cyclic beef heifers by administration of doses one order of magnitude higher than those reported previously in the literature for free steroids (Wiltbank et al., 1961; Brunner et al., 1969). Maternal peripheral plasma and fetal fluid ratios of conjugated and free oestrone during pregnancy are similar in magnitude (Eley et al., 1978) and were the basis for the dose used.

\section{Materials and Methods}

Six (6) beef heifers were injected subcutaneously with $28 \mathrm{mg}$ oestrone sulphate (oestrone-3sulphate, sodium salt; Sigma Chemical Co.) in $7 \mathrm{ml}$ corn oil beginning on Day 10 of the oestrous cycle (oestrus $=$ Day 0 ). Injections were continued once daily until detection of oestrus. The 6 control heifers were injected with $7 \mathrm{ml}$ corn oil following the same regimen. All animals were of the same approximate age (12 months) and weight $(300 \mathrm{~kg})$ and before treatment had exhibited regular oestrous activity determined by visual observation of oestrus and positive heat detectors (Kamar Inc.). Throughout the treatment period daily jugular blood samples were collected into heparinized tubes, immediately chilled in iced water and centrifuged; the plasma was stored at $-20^{\circ} \mathrm{C}$ until analysed for progestagen concentration. Progestagens were determined by the method of Abraham, Swerdloff, Tulchinsky \& Odell (1971) as described and validated in our laboratory by Chenault, Thatcher, Kalra, Abrams \& Wilcox (1975). All estimates were made in triplicate on dilutions from $0.5 \mathrm{ml}$ extracted plasma. The sensitivity was $25 \mathrm{pg}$ after $10 \%$ of the sample was taken to estimate recovery. The overall mean recovery was $85.6 \pm 2.8 \%$ with an intra-assay coefficient of variation of $15.9 \%$. After return to oestrus the 6 control animals were injected with $56 \mathrm{mg}$ oestrone sulphate/day using the regimen described above. The length of the cycle after the oestrogen treatment was recorded for all the animals. 


\section{Results and Discussion}

Results are presented in Table 1 . Treatment with 28 or $56 \mathrm{mg}$ oestrone sulphate/day significantly $(P<0.01)$ reduced cycle length compared to that of corn oil-injected animals. Pre- and post-treatment cycle lengths of treated cows were not different from those of controls. As shown in Text-fig. 1, plasma progestagens declined sooner in the treated heifers, falling from $4.83 \mathrm{ng} / \mathrm{ml}$ at Day 14 to oestrous levels $(<1 \mathrm{ng} / \mathrm{ml})$ at Day 18 . In contrast, progestagen concentrations in the control heifers declined from $6.02 \mathrm{ng} / \mathrm{ml}$ at Day 16 to $<1 \mathrm{ng} / \mathrm{ml}$ at oestrus $(21.2$ days). Therefore, luteal regression, based on cycle length and progestagen concentrations, began earlier in the heifers treated with $28 \mathrm{mg}$ oestrone sulphate/day.

It is clear, therefore, that with doses of 28 or $56 \mathrm{mg}$ oestrone sulphate/day (20 or $40 \mathrm{mg}$ oestrone equivalents/day) and the injection regimen (Day 10 until oestrus) used, oestrone sulphate is luteolytic in the cow. Administration of these high doses of conjugated steroid may have resulted in sufficient free oestrogens to override any possible luteotrophic nature of the

Table 1. Mean \pm s.e.m. oestrous cycle lengths (range in parentheses) for oestrone sulphate-injected or control heifers

\begin{tabular}{|c|c|c|c|}
\hline \multirow[b]{2}{*}{ Cycle } & \multirow[b]{2}{*}{ Control heifers } & \multicolumn{2}{|c|}{ Oestrone sulphate-injected heifers } \\
\hline & & $28 \mathrm{mg} /$ day & $56 \mathrm{mg} / \mathrm{day}^{*}$ \\
\hline Pretreatment & ${ }^{a} 22.5 \pm 0.56(20-24)$ & $22.0 \pm 0.55(21-24)$ & $21.2 \pm 0.75(18-23)$ \\
\hline Treatment & ${ }^{2} 21.2 \pm 0.75(18-23)$ & $\mathrm{b}_{1} 18.7 \pm 0.42(17-20)$ & $\mathrm{b}_{18.2} \pm 0.34(17-19)$ \\
\hline Post-treatment & - & $22.6 \pm 0.40(22-24)$ & ${ }^{2} 22.0 \pm 0.40(21-23)$ \\
\hline
\end{tabular}

Within columns and rows, values with different superscripts are significantly different, $P<0.01$ (least squares analysis of variance, orthogonal contrasts).

* These were the control heifers treated after their 'treatment' cycle of oil injections only.

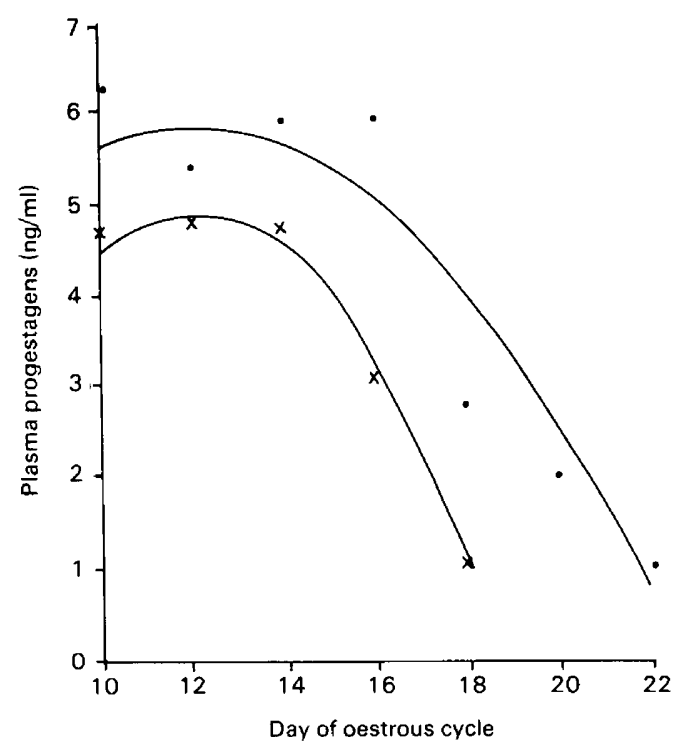

Text-fig. 1. Mean values for plasma progestagens in 6 control heifers $(\bullet)$ and 6 heifers treated with $28 \mathrm{mg}$ oestrone sulphate/day $(x)$. The regression lines were fitted by least squares analysis. 
conjugate. Indeed, although insufficient plasma was available for complete or very accurate estimations, analyses indicated that oestrone sulphate and oestrone concentrations were maximal in the plasma at $3.0 \mathrm{ng} / \mathrm{ml}$ and $500 \mathrm{pg} / \mathrm{ml}$ on Days 12 and 18 , respectively. Lower, less pharmacological, doses and/or administration of the same oestrone sulphate dose at other times of the cycle have not been tested and, until they are, oestrone sulphate must be considered, like oestradiol valerate, to be lytic. Whether the conjugated form is acting at the uterine or ovarian level or is unconjugated at these or other sites before action is not known.

This paper from the Florida Agricultural Experiment Station is Journal Series No. 949.

\section{References}

Abraham, G.E., Swerdloff, R., Tulchinsky, D. \& Odell, W.D. (1971) Radioimmunoassay of plasma progestin. J. clin. Endocr. Metab. 32, 619-624.

Brunner, M.A., Donaldson, L.E. \& Hansel, W. (1969) Exogenous hormones and luteal function in hysterectomized and intact heifers. J. Dairy Sci. 52, 18491854.

Chenault, J.R., Thatcher, W.W., Kalra, P.S., Abrams, R.M. \& Wilcox, C.J. (1975) Transitory changes in plasma progestins, estradiol, and luteinizing hormone approaching ovulation in the bovine. J. Dairy Sci. 58, 709-717.

Eley, R.M., Thatcher, W.W. \& Bazer, F.W. (1979) Hormonal and physical changes associated with bovine conceptus development. J. Reprod. Fert. 55 , 181-190.

Frank, M., Bazer, F.W., Thatcher, W.W. \& Wilcox, C.J. (1977) A study of prostaglandin $F_{2} \alpha$ as the luteolysin in swine. III. Effects of estradiol concentrations in the utero-ovarian vein of nonpregnant gilts. Prostaglandins 14, 1183-1189.

Gardner, M.L., First, N.L. \& Casida, L.E. (1963) Effect of exogenous estrogens on corpus luteum maintenance in gilts. J. Anim. Sci. 22, 132-134.

Perry, J.S., Heap, R.B., Burton, R.D. \& Gadsby, J.E. (1976) Endocrinology of the blastocyst and its role in the establishment of pregnancy. J. Reprod. Fert., Suppl. 25, 85-104.

Robertson, H.A. \& King, G.J. (1975) Estrogens and placental attachment in the cow. J. Anim. Sci. 41, 377, Abstr.

Wiltbank, J.N., Ingalls, J.E. \& Rowden, W.W. (1961) Effect of various forms and levels of estrogen alone or in combination with gonadotrophins on the estrous cycle of beef heifers. J. Anim. Sci. 20, 341-349.

Received 26 June 1978 